RETRACTION NOTE

\title{
Retraction Note: FABP4 contributes to renal interstitial fibrosis via mediating inflammation and lipid metabolism
}

Yujie Qiao, Liping Liu, Lianhong Yin, Lina Xu, Zeyao Tang, Yan Qi, Zhang Mao, Yanyan Zhao, Xiaodong Ma and Jinyong Peng

(c) The Author(s) 2021

Cell Death and Disease (2021)12:801; https://doi.org/10.1038/s41419-021-04084-x

Retraction Note to: Cell Death \& Disease https://doi.org/10.1038/ s41419-019-1610-5 published online 16 May 2019

The Editors-in-Chief have retracted this article because concerns have been raised regarding some of the figures. An investigation by the College of Pharmacy Dalian Medical University has established that during the course of revision, the bands of ACOX 1 and ACADL in rats were repeatedly pasted in Fig. $3 C$. In the Oil Red $O$ staining result of NFK-49F cells treated with/without LPS + siFABP4 in Fig. 4E, and immunofluorescence result of a-SMA and COL1A expressions in NRK-49F cells treated without LPS + siFABP4 in Fig. 4D, incorrect photos were provided due to file placement confusion. While the institutional investigation has not found evidence of misconduct, the Editors-in-Chief have found that, due to the errors, the findings are no longer reliable. The authors all agree with this retraction.

\begin{abstract}
Open Access This article is licensed under a Creative Commons Attribution 4.0 International License, which permits use, sharing, adaptation, distribution and reproduction in any medium or format, as long as you give appropriate credit to the original author(s) and the source, provide a link to the Creative Commons license, and indicate if changes were made. The images or other third party material in this article are included in the article's Creative Commons license, unless indicated otherwise in a credit line to the material. If material is not included in the article's Creative Commons license and your intended use is not permitted by statutory regulation or exceeds the permitted use, you will need to obtain permission directly from the copyright holder. To view a copy of this license, visit http://creativecommons. org/licenses/by/4.0/.
\end{abstract}

(c) The Author(s) 2021 